Отримано: 22 вересня 2018 р.

Прорецензовано: 5 жовтня 2018 р.

Прийнято до друку: 6 жовтня 2018 р.

e-mail: languagehub@ukr.net

DOI: $10.25264 / 2519-2558-2018-3(71)-3-5$
Artomova Yevheniia. Lexical and semantic nature of nicknames (based on the italian language). Наукові записки Начіонального університету «Острозька академія»: серія «Філологія». Острог : Вид-во НаУОА, 2018. Вип. 3(71), вересень. С. 3-5.

\author{
Yevheniia Artomova, \\ PhD of Philological Sciences, National Pedagogical Dragomanov University
}

UDC 811.161.2'373.2

\title{
LEXICAL AND SEMANTIC NATURE OF NICKNAMES (BASED ON THE ITALIAN LANGUAGE)
}

The article deals with the main types of nicknames as onomastic units of the internet discourse that are used by a virtual language personality. Their lexical characteristics and semantic nature have been described and disclosed. The author compares the notions of a pseudonym, a nickname and a virtual nickname, referring to the etymology of these concepts. Also, some definitions of terms have been given, taking into account the interpretations of some modern linguists. The work focuses on the fact that studying nicknames of a web-personality within the framework of virtual reality as a linguistic cultural phenomenon is not only popular, but also extremely relevant for modern linguistics. In the author's opinion, the virtual nickname is a unique phenomenon of nomination, important means of self-representation and image formation of the internet personality. The virtual names that had been selected from some authentic Italian web forums, internet chats and social networks served as the factual material. The communicants have not been limited by the age, social status, and occupation. It has been also emphasized that the meaning of the chosen virtual name can be disclosed only by the virtual language personality. Considering that the notions of a pseudonym and a nickname have some similar characteristics, the author only distributes the internet names according to the classification proposed by V. Dmitriev.

Key words: Internet discourse, communicator, self-representation, nickname, pseudonym, virtual linguistic personality, onomastics.

Артьомова Свгенія Олександрівна,

кандидат філологічних наук, Національний педагогічний університет ім. М. П. Драгоманова

\section{ЛЕКСИЧНА ТА СЕМАНТИЧНА ПРИРОДА НІКНЕЙМІВ (НА МАТЕРІАЛІ ІТАЛІЙСЬКОЇ МОВИ)}

У статті розглянуті основні види нікнеймів - ономастичних одиниць інтернет-дискурсу, якими користується віртуальна мовна особистість. Описані та розкриті лексичні характеристики та семантична природа інтернет-імен. Автор зіставляє поняття псевдонім, прізвисько та нікнейм, звертаючись до етимології цих понять. Також подається дефініція термінів, враховуючи тлумачення сучасних лінгвістів. У дослідженні акцентується увага на тому, щзо вивчення нікнеймів веб-особистості в рамках віртуальної реальності як лінгвокультурного феномена є не тільки популярним, але й надзвичайно актуальним для сучасної лінгвістики. На думку автора, нікнейм є унікальним явищем номінації, важливим засобом саморепрезентації та формування образу інтернет-особистості. Фактичний матеріал (віртуальні імена) було відібрано з автентичних італійських веб-форумів, інтернет-чатів та сочіальних мереж. При иььму вік, сочіальний статус, професія комунікантів не враховувались.

Ключові слова: інтернет-дискурс, комунікант, саморепрезентація, нікнейм, псевдонім, віртуальна мовна особистість, ономастика.

Артёмова Евгения Александровна,

кандидат филологических наук, Наџиональный педагогический университет им. М. П. Драгоманова

\section{ЛЕКСИЧЕСКАЯ И СЕМАНТИЧЕСКАЯ ПРИРОДА НИКНЕЙМОВ (НА МАТЕРИАЛЕ ИТАЛЬЯНСКОГО ЯЗЫКА)}

В статье рассмотрены основные виды никнеймов - ономастических единиц интернет-дискурса, которыми пользуется виртуальная языковая личность. Описаны и раскрыты их лексические характеристики и семантическая природа. Автор сопоставляет понятия псевдоним, прозвище и никнейм, обращаясь к этимологии этих понятий. Также дается дефиниция терминов, учитьвая толкования современных лингвистов. В исследовании акцентируется внимание на том, что изучение никнейма веб-личности в рамках виртуальной реальности как лингвокультурного феномена, является не только популярным, но и чрезвычайно актуальным для современной лингвистики. По мнению автора, никнейм представляет собой уникальное явление номинации, важное средство саморепрезентации и формирование образа интернет-личности. Фактическим материалом послужили виртуальнье имена, которые были отобраны с аутентичных итальянских веб-форумов, интернет-чатов и сочиальных сетей. При этом возраст, социальный статус, профессия коммуникантов не учитывались.

Ключевые слова: интернет-дискурс, коммуникант, саморепрезентация, никнейм, псевдоним, виртуальная языковая личность, ономастика.

Today, those researchers who are actively studying the Internet in all areas of linguistics offer a variety of classifications of internet-nicknames. We have already marked that in some ways, a virtual nickname is a pseudonym (Italian - soprannome), and it can be proved by the following: '...the word nickname is first recorded in the $15^{\text {th }}$ century: 'an eke name' (Old English eke, 'also') was an extra or additional name used to express such attitudes as familiarity, affection, and ridicule. Nicknames are usually applied to people, but places and things can have them too. Personal nicknames are commonest among children, but any closely-knit group will generate nicknames (such as the members of a family, sports team, or army unit). People who tend to be nicknamed are special friends or enemies, those in authority (teachers, officers, politicians), and anyone who has achieved notoriety (especially criminals). It is an important index of intimacy when we feel comfortable in using someone's nickname to their face' [4, p. 152].

Every person, when using the Internet and interacting, becomes a virtual language personality. According to T. Germasheva, 'the virtual language personality of a subject of a blog discourse includes a real language personality and possesses some special communicative competencies providing communication within a virtual environment - this personality realizes itself in a virtual discourse, 
forming a new dynamic image with a high degree of freedom. The behaviour of the virtual language personality is characterized by poly-identity, and the structure of self-representation includes such components as self-characterization and impact' [1, p. 42].

It is clear that the virtual language personality needs self-representation - an internet-name. There is a diversified synonymic row for such names today: a nickname, a web-name, an internet-name, a network name, a virtual nickname, etc., but the most suitable definition for these lexical units, in our opinion, is the following: 'nickname is a conditional or fictitious name for identification on the network. An artistic image of symbols that is created by a user for communication and self-representation in chat rooms, social networks and similar resources' [5]. M. Chabanenko defines the nickname as 'an informal personal name that is adopted by a speaker for the purpose of concealing the personality, which is the result of creativity, used in various spheres of mediated youth communication, made in writing' [3, p. 13].

In our opinion, the notion of a nickname is infused with the notion of a pseudonym. Any nickname, as well as any pseudonym, is selected by a person for some purpose. We absolutely agree with D. Crystal who emphasizes that 'many people adopt a name other than their original name for a particular purpose - perhaps to convey an image of some kind, to avoid some unpleasant associations, to make their identity more memorable, to hide their identity, or simply to make their name more pronounceable or easier to spell. Terminology varies, but pseudonym, pen-name, nom de plume, stage-name, byname, alias, and allonym have all been used, with different nuances, to identify the practice' [4, p. 152].

By definition of V. Dmitriev, the pseudonym is 'a common name for fictitious or modified names and surnames, those which replace a real name in signature' [2, p. 278].

The above definitions give us the grounds for an attempt to use the classification of some internet nicknames, proposed by D. Crystal and V. Dmitriev, for the distribution of the network names. The basis of V. Dmitriev's classification is the authors' principle of distribution of pseudonyms, primarily, according to their origin. From this perspective, one can distinguish between aliases associated with real names and unrelated ones. Pseudonyms of the first type hide a real name of an author by various means, but it can be found by deciphering the signature. Second type pseudonyms are quite diverse, they should be distinguished by functional meanings: some of them characterize the author on one side or the other; others represent it not as it is (so-called 'mask name'); the third ones are only intended to provide incognito.

It is essential to highlight that modern linguists are doing great research concerning nicknames, the virtual language personality and the Internet on the whole. Among such scientists it is worth mentioning such names as O. Belinskaya, M. Chabanenko, L. Kompantseva, O. Lutovinova, G. Trofimova, A. Zhyckina and many others.

Since in our previous works we have already described some characteristics that are different or common in these lexical units (nickname and pseudonym), we consider it reasonable to use the classification of pseudonyms, proposed by V. Dmitriev to reveal the semantic nature of internet nicknames - this is the purpose and tasks of our present work. We consider our article to be relevant because analyzing nicknames based on the Italian language has been made for the first time, and it needs further detailed studying.

So, we have analyzed some Italian virtual nicknames, which we have categorized as follows:

- autonyms (Italian - autonimo): Emanuela Venturini, Ruggero Ballotta, Nicola DeFranco, Freddo Cavinato, Anna Pavarotti, Patrizia Primo, Karlo Giordano, Maria Ricci, Antonio Costa, Giueseppe Moretti.

Prenonym is a kind of the autonym, e. g.: Luisa, Barbara, Marchella, Gelsomino, Lucas, Eleonora, Santa, Marinda, Kristopher, Leandro, Bruno, Lombardi, Bianchi.

- alonym, or heteronym. These may be the names of favourite or unfavourite popular performers, actors and actors, heroes of books or computer games. Internet nicknames can repeat the names of writers, other well-known people, or may be the names of funny beings invented by the person or someone else: Celentano, enric_O_caruso, Gianni_Rodari. Such nicknames can tell about a person's hobby, moral principles and principles embodied, materialized in a chosen for nickname character.

There is also such notion as a heronym which is a kind of alonyms, for example: AntEroS (the Italian God of love and passion), jove-86 (the sky God), umbri_a (goddess of shadows).

Also, heronyms are quite common when choosing internet-nicknames. This is, first of all, due to the development of role-playing online games. Often, the users themselves explain the choice of virtual nicknames on forums.

For virtual games, the network nicknames are chosen very carefully so that the name necessarily has some meaning and emotional colour. The name can reveal, for example, a person's intelligence, etc. Online games have the largest percentage of names in English. This is due to the fact that, besides the fact that English is international, the Internet also brings people from all over the world. In the opinion of many users, this is already enough for an English-speaking virtual nickname. A significant percentage of the network nicknames are fictitious names or names of the heroes of online games: Faeo, Oliaga, Arv, Ennyah, Furii, Tansie, Thwacka, Nickelplate;

- anagram (Italian - anagramma), for instance, nio-anto (Antonio), vernO in (inverno), inabamb1997 (bambina), ocouc-15 (cuoco);

- apoconym: Frodita-20 (Afrodita), gina (Reginetta), Cenza (Vincenza);

- aristonym, for example, cont_e, Cardinal-1235, coronata-88;

- geonym, or toponym. The toponyms are used very often on the Internet: Roma_italy, pisa15, FiRenZe_09, cataNIA, ferrara.01;

- hydronym: aRnO, adige-17, piave_2000, lambro00, rubicone.24;

- entomonym, for example: ZanZarA (mosquito), MPiattola ${ }^{M}$ (cockroach), formica (antler), ragno_11 (spider);

- ethnonym: italiana-99 (italian), russo_olya, spagnola_1971;

- zoonym Examples: spinosso-111 (hedgehog), volpe* (fox), scimmia_1977 (monkey), lep_re (hare), serpente (snake);

- ichthyonym: luccio-18 (pike), carpa.1.1 (carp), acerinaaa (pope);

- ornithonym. Such network nicknames include: Passero-39 (sparrow), usignolo (nightingale), struzzo_54 (ostrich). The choice is explained by the Italian user with the nickname di usignolo: 'Il mio nickname cela il lavoro che svolgo, sono soprano e tanti mi dicono che la mia voce que quella di un usignolo :-)!' [http://www.trnd.com/it/blog/2011/07/04/i-nostri-nickname/] ('My profession is hidden in my nickname, I sing soprano, and many people tell me that my voice is like a nightingale').

- phytonym: soffione-2010 (dandelion), Rosellina (briar), ${ }^{* * *}$ camo*milla*** (camomile), gelsomino (jasmine); 
- phrenonym: Bieco Maschietto (wicked guy), otti_mista (optimist), tragediante_89(tragic actor), zuzzurellone.1 (happy person);

- chromatonym: grigio066 (grey), angelo_bianco (white angel), aZzuRro (blue), nero_NERO (black), aranciat0 (orange), marrone_12_12_2012 (brown).

According to some other linguistic works, there are also such kinds of internet names as antionym, astronym, matronymic, metagram, metonym, neutronym and many others. The Internet users also use contamination, Latinism, etc. when creating the web name.

Among the nicknames one can often meet the initials (initial letters of the first and last names, or a name and patronymic, or a given name, a surname); incognito names (a signature that emphasizes the author's desire to remain unknown): $Z, N-15, Y Y Y, x x-x$, $* *_{r} * *, t\{\}$; title names (a signature indicating the title or position of the author): aVVocato, ilmaestra, medico_76, studentessa.24, pittore-1983.

Also, we have to note that a large number include a group of nicknames that do not correspond to any classification, that is, they have no specific meaning (if there is no explanation of the user): sf76, s3rgLo, rem24, polson, PG3010, nickst, mga000, gaus, fon286, EUJMP, Li 37, oLLLa, 911sct,MjE,f-16,@(0o)@,!!!mmm\}\}\}, GEO, kl8, lolo, gq5, z ZZZ, bpgchlnbo, cnjuhfv, iioo, akita, zup120, hsif54, ogogo, p.i.f, qwertyl, ketro, Ma79, bctaty2.

As it can be seen, the above examples of the virtual nicknames are a random set of letters and numbers or non-existent words; sometimes users encrypt their personal data, etc.

Thematic Italian online names within the Ukrainian and English forums or chats are rarely used. They can be viewed on Italian pages of the network or on the pages of those who are interested in the Italian language:: Francesco, Silvana, Chiarra, positivo, greta12, Federico, Giovanni, abbronzamento, uno, trapezio73, f.ostuzzi, c?h?i?, i-t-a-l-y, gelsomino, 88cielo88, mazza, bambino, aprile87,mela@,steLLLa,rondine32.

There is a variety of different nicknames on thematic forums, for example, some Italian forums for acquaintances have the following: fred30, nic2011, angelonero.VR, xxMOULINROUGExx, frack1972, gionpac, aniellodivaio26, vigamote, pos86, dan67, veneredolce74, руррA, Ziba64, stella.229, DIAMANTINA.70, XWhite.DevilX, MITICO84.RM, dentrolestelle, vince51, lele.1968, Franceskyna, nostromo.1910, Lamante2010, angellobianco, wledonne.83, minavagante1, maxmax.70, shark196o, 1961nick, robertost, Diletta.xs, Reddragon.78, jason.22, runa.BO, occhiazzurri85.MI.

One Italian music forum offers the following variations: ultimo884, GIAMATURO, InFiniTy.70, hosceltote, nishgabros, castore. polluce, mirco.SP, malato.2010, rasato73, amore.2011, biondona90, ninfo72, simpaempatico, gio130872, 22mirko, boscoabbandonato, ksam, Mejopezzo, simo589, lecosechevivi, le.le2, ansara, mondomotori86, carinoRM80, saturn.76, trichecoMANNARO, IlMaestro.69, caffenero.66, angelo.speciale, MiSs.SiMpSoN, sunshine.20, Orfeus, io.21, BELLOeeDANNATO, blaseba.

Another Italian forum of film-lovers fixes such nicknames as: beppesv58, MadSamurai, Falanto, lucy.bsx., massrossuomo, Palmira75, Chris0077, p.ocho87, sensualee, desdiego, Ellysvin, ildiko, alex.shov, aleffiuomo, om3ga005, dvdgirl, pablo242, monello.1973, robbj.91, morriGUN, ironico1, slaytimuomo, coppiabrasile, francyo78, elyelyely, costanzamv, claud45.PD, pudim, gatto, gialla_32, babyspietato85, cavaliere., MaDIroNuomo, NeMiKoPuBLiKO.N1, lucioooooouomo, 20.Kikka, cuore.rosa, m.orookkiazzurri, mariaclaudia, Stefy.20, Jemife, ETHAN57, PrincipeAzzurro85, babuccia669, AmberMoore, Limpida74, alfonsine2005, ancona2000, d.ucitta, alidoro, segretario91, 70pasqui, gibsy.

The Italian chat www.chatta.it: Blured1983, dolceluna37, fatinabrutta, S.trunzella, wankel, yesy.91, RositaMorada1982, stephan68, DAVID.72, egeria26, 2011anna67, bier, medaio, neko.RM, mkv1970, Sonny1956, riccardo77.MI, olelunaMS, piccolastrega24, gwenever.

Thus, on the one hand, a user, when create a network nickname, can rely on the subject of the forum (if the forum is linguistic, then, an internet name is associated with linguistics, as a rule; if the forum is about sports - the participant of this forum often chooses the names of favorite sportsman, etc.). On the other hand, some users do not pay attention to the topics of the forum and choose usual nicknames that are casual and real; sometimes the user does not sign at all (in such cases, the system automatically calls the user 'guest').

Semantics of nicknames is a complex issue, because in some cases it is impossible to understand what the user wanted to 'transfer' by his or her internet name. Some users, choosing web names, turn to dictionaries so that their nickname has some meaning.

It should be noted that there is the tendency to use famous quotations, utterances, puns, idioms, etc., among which we observe proverbs and sayings: Roma-e-Eterna (Rome is eternal), non c'e rosa senza spine (there are no roses without thorns).

Modern linguists offer the most diverse classifications and varieties of internet names, placing on the first place the task of revealing their subject as accurately as possible. On the other hand, users invent new and new names, and these web names have to become a necessary linguistic issue.

In conclusion, it has to be emphasized again that the semantic and lexical analysis of virtual nicknames is rather complicated, since they are often without any explanation, and without the user it is impossible to determine a real meaning of the internet name. Some network names reflect the features of the person's appearance or character, emotional state, professional activity, etc. Sometimes you can define a person's age, gender, hobbies, and others. The web nickname has to be considered as a linguistic phenomenon and needs more modern research for many reasons, such as: any nickname can carry different message, it is changeable, it is a mix of various linguistic and cultural tendencies, in comparison with other anthroponyms the nickname is a complex lexical unit, it can be studied in different fields and parts of linguistics (psycholinguistics, sociological linguistics, onomastics, stylistics, etc.).

\section{Literature:}

1. Гермашева Т. М. Виртуальная языковая личность в пространстве блог-дискурса. Научный журнал «Вестник АГУ». Выпуск 2 (140). 2014. C. 39-43.

2. Дмитриев В. Г. Скрывшие имя свое (Из истории анонимов и псевдонимов). М. : Наука, 1977. 313 с.

3. Чабаненко М. Г. Молодежный дискурс как реализация типовой и индивидуальной языковой личности: автореф. дис. ... канд. филол. наук: 10.02.01. М., 2007. 21 с.

4. The Cambridge Encyclopedia of the English language / David Crystal. Second edition. Cambridge university press, 2015. 499 p.

5. Electronic resource. Access mode: http://slovoborg.su/.

6. Electronic resource. Access mode: http://www.trnd.com/it/blog/2011/07/04/i-nostri-nickname/. 